\title{
RYNEK BROKERSKI W POLSCE A ZMIANY OTOCZENIA EKONOMICZNEGO
}

\section{Wprowadzenie}

Brokerzy prowadzący działalność na polskim rynku ubezpieczeniowym muszą stawić czoła zmieniającym się warunkom rynkowym. Przede wszystkim rosnąca intensywność konkurencji oraz dynamiczne zmiany w otoczeniu powodują, że brokerzy muszą w większym stopniu zwracać uwagę na efektywność i dywersyfikację prowadzonej działalności. Niepokojące zjawiska na rynku ubezpieczeniowym tj. m.in.: malejące tempo wzrostu przypisu składki przy rosnącej ekspozycji, rosnąca szkodowość i koszty działalności ubezpieczeniowej, malejące dochody $\mathrm{z}$ inwestycji (środowisko niskich stóp procentowych), rosnąca koncentracja działalności, malejąca liczba zakładów ubezpieczeń i jednocześnie duża liczba zakładów ubezpieczeń walczących o udziały w rynku (wojna cenowa), a także duża rotacja kluczowych pracowników i nadmierna presja przełożonych na wyniki i narzucanie nierealnych planów powodują, że poziom konkurencji na polskim rynku ubezpieczeniowym jest bardzo wysoki. Czynniki te przekładają się bezpośrednio na sytuację na rynku brokerskim. Celem prezentowanego artykułu jest próba oceny wpływu zmian w otoczeniu ekonomicznym na rynek brokerski w Polsce oraz określenie wyzwań stojących przed firmami brokerskimi w najbliższych latach w Polsce. 


\section{Rozwój rynku brokerskiego w Polsce w latach 2008-2015}

Ogólna liczba zarejestrowanych brokerów na dzień 31 grudnia 2015 roku wyniosła 1315 , z czego 1276 podmiotów wykonywało działalność w zakresie ubezpieczeń, a jedynie 39 w zakresie reasekuracji. Wartość ta oznacza przyrost liczby zarejestrowanych brokerów o 7\% w stosunku do 2014 roku. Liczba brokerów ubezpieczeniowych i reasekuracyjnych wzrosła w ostatnich 8 latach z 905 do 1 315, tj. o 45,3\% (zob. tab. 1). Do końca 2015 r. zostało wydanych ogółem 2440 zezwoleń na wykonywanie działalności brokerskiej, w tym 2364 w zakresie ubezpieczeń (1 664 osobom fizycznym i 700 osobom prawnym) oraz $76 \mathrm{w}$ zakresie reasekuracji (odpowiednio: 18 i 58) [UKNF 2016].

\begin{tabular}{|l|c|c|c|c|c|c|c|c|}
\cline { 2 - 9 } \multicolumn{1}{c|}{} & 2008 & 2009 & 2010 & 2011 & 2012 & 2013 & 2014 & 2015 \\
\hline $\begin{array}{l}\text { Liczba brokerów } \\
\text { ubezpieczeniowych } \\
\text { ogółem }\end{array}$ & 888 & 914 & 936 & 1009 & 1077 & 1145 & 1196 & 1276 \\
\hline $\begin{array}{l}- \text { w tym osoby } \\
\text { fizyczne }\end{array}$ & 633 & 646 & 654 & 710 & 738 & 775 & 801 & 828 \\
\hline $\begin{array}{l}- \text { w tym osoby } \\
\text { prawne }\end{array}$ & 255 & 268 & 282 & 299 & 339 & 370 & 395 & 448 \\
\hline $\begin{array}{l}\text { Liczba brokerów } \\
\text { reasekuracyjnych } \\
\text { ogółem }\end{array}$ & 17 & 17 & 18 & 20 & 24 & 31 & 33 & 39 \\
\hline $\begin{array}{l}\text { Liczba brokerów } \\
\text { ogółem }\end{array}$ & 905 & 931 & 954 & 1029 & 1101 & 1176 & 1229 & 1315 \\
\hline
\end{tabular}

Tabela 1. Liczba brokerów w Polsce według określonych kryteriów, 2008-2015

Źródło: obliczenia własne na podstawie danych KNF [UKNF 2009; UKNF 2010; UKNF 2011; UKNF 2012; UKNF 2013; UKNF 2014; UKNF 2015; UKNF 2016].

Wartość ulokowanych przez brokerów składek w zakładach ubezpieczeń w roku 2015 wyniosła ogółem $8027 \mathrm{mln}$ zł. Oznacza to spadek o $3,8 \%$ w odniesieniu do poprzedniego roku. W Dziale I nastąpił spadek o 9,4\%, a w Dziale II o 1,3\% w stosunku do 2014 roku. Pod względem wartości lokowanych składek, mimo znacznej liczby zakładów notyfikowanych, 94\% składek brokerzy ulokowali w zakładach ubezpieczeń $\mathrm{z}$ siedzibą w Polsce, a tylko 6\% w zakładach notyfikowanych i oddziałach zakładów zagranicznych. W latach 2008-2015 wartość ulokowanych za pośrednictwem brokerów składek w zakładach ubezpieczeń wzrosła prawie dwukrotnie (zob. tab. 2).

Głównym źródłem przychodu z działalności brokerskiej są prowizje uzyskiwane od zakładów ubezpieczeń. W 2015 roku całkowite przychody brokerów z tego tytułu wyniosły $1046 \mathrm{mln}$ zł, co oznacza wzrost przy- 
chodów w stosunku do roku poprzedniego o $15,6 \%$. Jest to kolejny rok ze wzrostem dynamiki w porównaniu do ostatnich ośmiu lat. W tym okresie liczba zarejestrowanych i działających brokerów wzrosła o 45\%, a przychody prowizyjne o 113\%. Wysokość średniej prowizji była zależna od działu ubezpieczeń (life vs. non-life). Zdecydowanie wyższe prowizje brokerzy otrzymywali w Dziale II (od 12,1\% do 16,0\%), natomiast w ubezpieczeniach na życie oscylowały one pomiędzy 6-7\% (zob. tab. 2).

\begin{tabular}{|l|r|r|r|r|r|r|r|c|}
\cline { 2 - 9 } \multicolumn{1}{c|}{} & 2008 & \multicolumn{1}{c|}{2009} & 2010 & \multicolumn{1}{c|}{2011} & \multicolumn{1}{c|}{2012} & 2013 & 2014 & 2015 \\
\hline $\begin{array}{l}\text { Wartość składki ulo- } \\
\text { kowanej (w mln zł) }\end{array}$ & 4151 & 4167 & 4449 & 5925 & 6985 & 6545 & 8344 & 8027 \\
\hline $\begin{array}{l}\text { Dynamika ulokowa- } \\
\text { nych składek }\end{array}$ & - & $0,39 \%$ & $6,78 \%$ & $33,16 \%$ & $17,90 \%$ & $-6,30 \%$ & $27,48 \%$ & $-3,8 \%$ \\
\hline $\begin{array}{l}\text { Przychody ogółem } \\
\text { uzyskane przez } \\
\text { brokerów z tytułu } \\
\text { prowizji (w mln zł) }\end{array}$ & 492 & 559 & 583 & 658 & 842 & 901 & 905 & 1046 \\
\hline $\begin{array}{l}\text { Dynamika przycho- } \\
\text { dów brokerskich }\end{array}$ & - & $13,51 \%$ & $4,33 \%$ & $12,86 \%$ & $27,97 \%$ & $7,03 \%$ & $0,44 \%$ & $15,58 \%$ \\
\hline $\begin{array}{l}\text { Średnia prowizja } \\
\text { brokerska dz. I (\%) }\end{array}$ & $\mathbf{5 , 9 \%}$ & $\mathbf{6 , 2 0 \%}$ & $\mathbf{6 , 5 \%}$ & $\mathbf{6 , 3} \%$ & $\mathbf{5 , 8} \%$ & $\mathbf{7 , 6 \%}$ & $\mathbf{5 , 8 \%}$ & $\mathbf{7 , 5 \%}$ \\
\hline $\begin{array}{l}\text { Średnia prowizja } \\
\text { brokerska dz. II (\%) }\end{array}$ & $\mathbf{1 2 , 2 \%}$ & $\mathbf{1 4 , 6 0 \%}$ & $\mathbf{1 5 , 0 \%}$ & $\mathbf{1 2 , 4 \%}$ & $\mathbf{1 2 , 1 \%}$ & $\mathbf{1 6 , 0 \%}$ & $\mathbf{1 3 , 5 \%}$ & $\mathbf{1 5 , 2 \%}$ \\
\hline
\end{tabular}

Tabela 2. Wysokość ulokowanej przez brokerów składki i przychody ogółem uzyskane z tytułu prowizji od zakładów ubezpieczeń w latach 2008-2015 Źródło: obliczenia własne na podstawie danych KNF [UKNF 2009; UKNF 2010; UKNF 2011; UKNF 2012; UKNF 2013; UKNF 2014; UKNF 2015; UKNF 2016].

\begin{tabular}{|l|r|r|r|r|r|r|r|r|}
\cline { 2 - 9 } \multicolumn{1}{c|}{} & 2008 & 2009 & 2010 & 2011 & 2012 & 2013 & 2014 & 2015 \\
\hline $\begin{array}{l}\text { Przychody ogółem } \\
\text { uzyskane przez } \\
\text { brokerów z tytułu } \\
\text { prowizji (w mln zł) }\end{array}$ & 492 & 559 & 583 & 658 & 842 & 901 & 905 & 1046 \\
\hline $\begin{array}{l}\text { Struktura przycho- } \\
\text { dów: osoby fizyczne }\end{array}$ & $22,8 \%$ & $16,4 \%$ & $15,0 \%$ & $16,1 \%$ & $15,0 \%$ & $13,2 \%$ & $13,4 \%$ & $11,3 \%$ \\
\hline $\begin{array}{l}\text { Struktura przycho- } \\
\text { dów: osoby prawne }\end{array}$ & $77,2 \%$ & $83,6 \%$ & $85,0 \%$ & $83,9 \%$ & $85,0 \%$ & $86,8 \%$ & $86,6 \%$ & $88,7 \%$ \\
\hline $\begin{array}{l}\text { Odsetek przycho- } \\
\text { dów ogółem } \\
\text { 25 największych } \\
\text { brokerów }\end{array}$ & $\mathbf{5 2 , 2 \%}$ & $\mathbf{5 5 , 1 \%}$ & $\mathbf{5 8 , 6 \%}$ & $\mathbf{5 9 , 1 \%}$ & $\mathbf{5 7 , 4 \%}$ & $\mathbf{6 3 , 4} \%$ & $\mathbf{5 8 , 4 \%}$ & $\mathbf{6 2 , 9 \%}$ \\
\hline $\begin{array}{l}\text { Struktura } \\
\text { przychodów: Dział I }\end{array}$ & $9,6 \%$ & $13,2 \%$ & $12,2 \%$ & $12,3 \%$ & $13,3 \%$ & $14,5 \%$ & $13,8 \%$ & $16,4 \%$ \\
\hline $\begin{array}{l}\text { Struktura } \\
\text { przychodów: Dział II }\end{array}$ & $90,4 \%$ & $86,8 \%$ & $87,8 \%$ & $87,7 \%$ & $86,7 \%$ & $85,5 \%$ & $86,2 \%$ & $83,6 \%$ \\
\hline
\end{tabular}

Tabela 3. Struktura przychodów brokerskich uzyskanych z tytułu prowizji od zakładów ubezpieczeń w latach 2008-2015 Źródło: obliczenia własne na podstawie danych KNF [UKNF 2009; UKNF 2010; UKNF 2011; UKNF 2012; UKNF 2013; UKNF 2014; UKNF 2015; UKNF 2016]. 
Mimo że osoby fizyczne stanowią blisko 65\% wszystkich zarejestrowanych brokerów, to wygenerowały one zaledwie 11,3\% całkowitych przychodów z tytułu prowizji od zakładów ubezpieczeń w 2015 roku. Ich udział w przychodach z roku na rok maleje (z 22,8\% w 2008 roku do 11,3\% w 2015). Dwudziestu pięciu największych, według przychodów, brokerów uzyskało w badanym okresie od 52\% do 63\% przychodów brokerskich ogółem, następuje więc duża koncentracja działalności na rynku brokerskim. Ponadto przeważająca część przychodów jest generowana przez składki z Działu II (84\% w 2015 roku), mimo stopniowego powolnego przesuwania tego strumienia w kierunku Działu I (z 9,6\% w 2008 roku do 16,4\% w 2015 roku) (zob. tab. 3).

\section{Wpływ zmian w otoczeniu ekonomicznym na branżę brokerską}

Teoria pośrednictwa identyfikuje cztery główne obszary, w których pośrednicy ubezpieczeniowi odgrywają szczególnie pozytywną rolę. Należą do nich: korzyści skali, zmniejszenie kosztów poszukiwania i dopasowywania ochrony ubezpieczeniowej, łagodzenie skutków zjawiska "negatywnej selekcji” lub „asymetrii informacji” oraz łagodzenie skutków „moral hazard”. Rola ta ujawnia się, w szczególności na rynkach krajów Europy Środkowo-Wschodniej, gdzie brokerzy ubezpieczeniowi i reasekuracyjni stymulują rynek i są podmiotami wprowadzającymi dużą innowacyjność na rynku zarządzania ryzykiem.

Sytuacja rynku brokerskiego jest odzwierciedleniem jego szczególnej roli i usytuowania oraz relacji brokera na rynku ubezpieczeniowym. Zakład ubezpieczeń jest głównym dostawcą (pojemności ubezpieczeniowej) dla realizacji usług brokerskich i jednocześnie pośrednio ich nabywcą (przyjmującym ryzyko od klientów brokerów), co ma wpływ na szczególne znaczenie wzajemnych sił oddziaływania dostawców i nabywców oraz ich zależności.

Ze względu na dużą zależność rynku brokerskiego od rynku ubezpieczeniowego i gospodarki w kolejnych częściach artykułu zostaną przedstawione czynniki wpływające na stan rynku brokerskiego w Polsce przez opisanie wpływu najważniejszych zmian w otoczeniu branżowym (systematycznym) i makroekonomicznym (systemowym) na rynek brokerski.

Ocena wpływu zewnętrznych czynników ekonomicznych ma w dużej mierze charakter jakościowy, wiele elementów tej oceny można jednak skwantyfikować. Ocena otoczenia działalności brokerskiej powinna 
pozwolić na oszacowanie poziomu ryzyka, na jaki jest narażony broker ubezpieczeniowy działający na danym rynku. Szczególnie w obrocie międzynarodowym zwraca się uwagę na kraj pochodzenia brokera i zakładu ubezpieczeń. Ocena ta ma za zadanie przede wszystkim zidentyfikować elementy, które w przyszłości mogą potencjalnie zagrozić pozycji finansowej brokera. Dlatego też spośród wszystkich czynników zewnętrznych oddziałujących na brokerów przedstawione zostały te, których negatywny wpływ może być najbardziej znaczący.

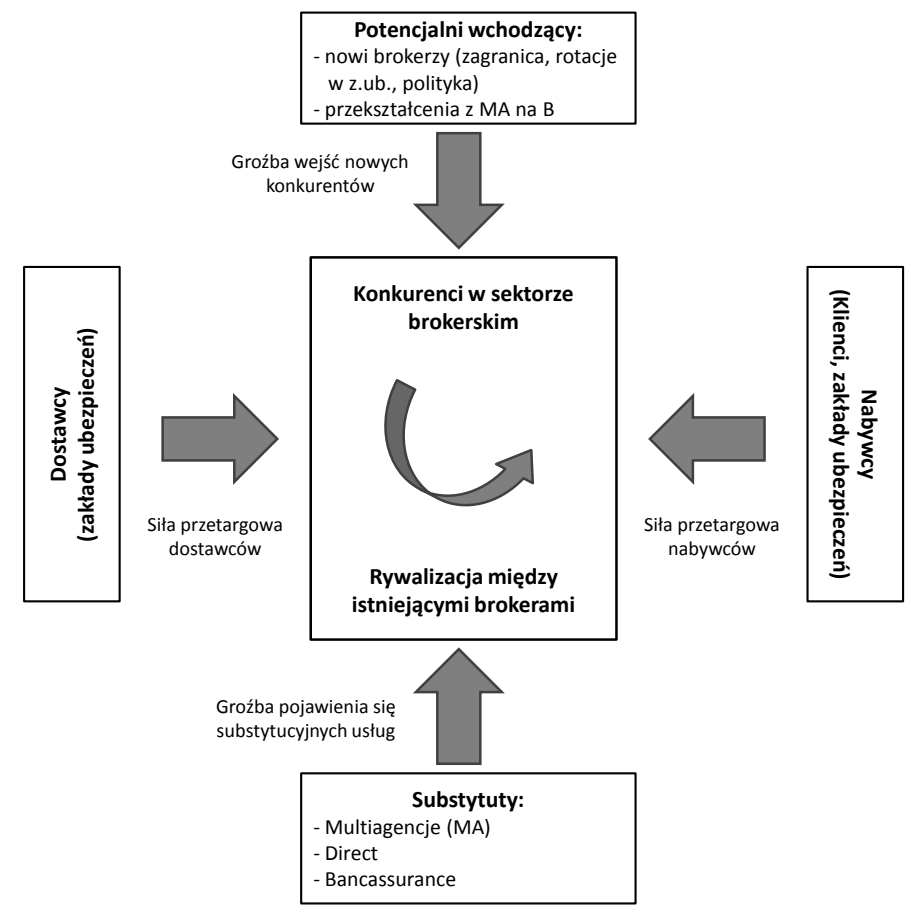

Rysunek 1. Czynniki wpływające na stan rynku brokerskiego Źródło: opracowanie własne na podstawie: Porter [2006].

\subsection{Czynniki branżowe (systematyczne) wpływające na branżę brokerską}

Ocena wpływu dynamiki branży dotyczy przede wszystkim tych zmian, które przez wpływ na strukturę i zachowania konkurencyjnych brokerów i innych podmiotów rynku zwiększą intensywność konkurencji, a przez to pogorszą wyniki branży (zob. tab. 4). 


\begin{tabular}{|c|c|c|}
\hline Czynnik & Opis & Wpływ na sytuację konkurencyjną brokerów \\
\hline $\begin{array}{l}\text { Potencjalne } \\
\text { zagrożenie } \\
\text { nowymi } \\
\text { wejściami }\end{array}$ & $\begin{array}{l}\text { Wpływ na rosnącą kon- } \\
\text { kurencyjność branży }\end{array}$ & $\begin{array}{l}\text { - Nowi brokerzy rozpoczynający działalność } \\
\text { na rynku, chcąc zdobyć klientów wprowadzają } \\
\text { innowacje i lepszą obsługę klientów, ale mogą } \\
\text { także "psuć rynek" poprzez przechodzenie } \\
\text { na ceny dumpingowe (niskie "fee" zamiast pro- } \\
\text { wizji). } \\
\text { - Restrukturyzacja branży ubezpieczeniowej } \\
\text { i presja kosztowa zwiększa ryzyko zwolnień gru- } \\
\text { powych (w } 2016 \text { r. zakłady zwolniły około } 1500 \\
\text { pracowników, tj. ok. } 6 \% \text { ogółu zatrudnionych). } \\
\text { - Odchodzący pracownicy bardzo często tworzą } \\
\text { nowe firmy pośrednictwa ub. bądź zasilają szere- } \\
\text { gi konkurencji. }\end{array}$ \\
\hline Substytuty & $\begin{array}{l}\text { Pojawienie się substy- } \\
\text { tucyjnych produktów } \\
\text { i usług }\end{array}$ & $\begin{array}{l}\text { - Pojawienie się dużych multiagencji, nowych } \\
\text { kanałów dystrybucji typu bancassurance, ale } \\
\text { także direct (bezpośrednia konkurencja ze stro- } \\
\text { ny zakładu ubezpieczeń). } \\
\text { - Rosnąca tendencja do zmiany agencji wyłącz- } \\
\text { nych na multiagencje. }\end{array}$ \\
\hline $\begin{array}{l}\text { Ogólna kon- } \\
\text { kurencyjność } \\
\text { i zmienność } \\
\text { branży }\end{array}$ & $\begin{array}{l}\text { Wpływna poziomwyna- } \\
\text { grodzenia (ryzyko pro- } \\
\text { wadzenia działalności } \\
\text { i osiąganie rentowności) }\end{array}$ & $\begin{array}{l}\text { - Wysoka konkurencyjność i duża zmienność } \\
\text { wyników branży lub niektórych segmentów } \\
\text { (np. ubezpieczenia na życie czy komunikacyjne) } \\
\text { mają wpływ na rentowność i bezpieczeństwo za- } \\
\text { kładów ubezpieczeń. } \\
\text { - Jednocześnie wojna cenowa przy systemie } \\
\text { wynagrodzenia prowizyjnego (od składki) po- } \\
\text { woduje znaczna obniżke podstawy naliczenia } \\
\text { wynagrodzenia brokerskiego. } \\
\text { - Polska jest krajem, w którym cena jest ciągle } \\
\text { głównym driverem wyboru ubezpieczenia (68\% } \\
\text { badanych przez KPMG, grudzień } 2015 \text { r.) } \\
\text { [KPMG 2015]. }\end{array}$ \\
\hline $\begin{array}{l}\text { Zależność od } \\
\text { nabywców }\end{array}$ & $\begin{array}{l}\text { Wpływna poziomwyna- } \\
\text { grodzenia (ryzyko pro- } \\
\text { wadzenia działalności } \\
\text { i osiąganie rentowności) }\end{array}$ & $\begin{array}{l}\text { - Nieoczekiwane i głębokie zmiany wyników } \\
\text { mogą powodować zagrożenie, szczególnie dla } \\
\text { brokerów opartych na pojedynczych klientach, } \\
\text { bez dywersyfikacji działalności. }\end{array}$ \\
\hline $\begin{array}{l}\text { Zależność od } \\
\text { dostawców }\end{array}$ & $\begin{array}{l}\text { Wpływna poziomwyna- } \\
\text { grodzenia (ryzyko pro- } \\
\text { wadzenia działalności } \\
\text { i osiąganie rentowności) }\end{array}$ & $\begin{array}{l}\text { - Restrukturyzacja branży ubezpieczeniowej } \\
\text { i presja kosztowa mogą utrudnić osiąganie do- } \\
\text { tychczasowych dobrych warunków } \\
\text { prowizyjnych. }\end{array}$ \\
\hline $\begin{array}{l}\text { "Long tail" } \\
\text { - okres inku- } \\
\text { bacji szkód } \\
\text { w szkodach } \\
\text { OC brokera }\end{array}$ & „Kultura roszczeniowa” & $\begin{array}{l}\text { - W przypadku obsługi specyficznych ryzyk ist- } \\
\text { nieje zwiększone zagrożenie popełnienia błę- } \\
\text { dów przez pracowników brokera, co przy coraz } \\
\text { większej świadomości prawnej podmiotów i po- } \\
\text { szerzaniu się zjawiska "kultury roszczeniowej" } \\
\text { (szukanie źródła finansowania szkody na ze- } \\
\text { wnątrz) może spowodować zwiększone zagro- } \\
\text { żenie OC brokera, nawet po zakończeniu współ- } \\
\text { pracy z klientem. }\end{array}$ \\
\hline
\end{tabular}

Tabela 4. Najważniejsze elementy analizy zmian w ramach branży

Źródło: opracowanie własne na podstawie: Lisowski i Jaworski [2001]; Porter [2006];

Lisowski [2015]. 


\subsection{Czynniki makroekonomiczne wpływające na branżę brokerską}

Analiza otoczenia makroekonomicznego obejmuje najważniejsze wskaźniki, które decydują o kondycji całej gospodarki, a przez to w znaczący sposób o wynikach brokerów takie jak, m.in.: wzrost gospodarczy, zmiany na rynku pracy, inflacja, poziom inwestycji zagranicznych, polityka kursów walutowych czy stan i efektywność rynku ubezpieczeniowego (zob. tab. 5).

\begin{tabular}{|c|c|c|}
\hline Czynnik & Opis & Wpływ na sytuację konkurencyjną brokerów \\
\hline 1 & 2 & 3 \\
\hline $\begin{array}{l}\text { Wzrost } \\
\text { gospodarczy }\end{array}$ & $\begin{array}{l}\text { Wpływ zmian PKB na } \\
\text { składkę oraz odszko- } \\
\text { dowania, zachowanie } \\
\text { klientów }\end{array}$ & $\begin{array}{l}\text { - PKB w dużej mierze wpływa na dynamikę przypi- } \\
\text { su składki, spadek lub zwolnienie trendu wzrosto- } \\
\text { wego, zbyt szybki jej wzrost może stanowić zagro- } \\
\text { żenie. } \\
\text { - Niektóre rodzaje ubezpieczeń mogą być wrażliwe } \\
\text { na wahania koniunktury gospodarczej, na przykład } \\
\text { ubezpieczenia kredytów i gwarancje ubezpiecze- } \\
\text { niowe. } \\
\text { - Wzrost gospodarczy sprzyja zwiększaniu budże- } \\
\text { tów na zarządzanie ryzykiem i innowacje ubezpie- } \\
\text { czeniowe (np. dodatkowe zabezpieczenia, PAYD). }\end{array}$ \\
\hline $\begin{array}{l}\text { Zmiany na rynku } \\
\text { pracy }\end{array}$ & $\begin{array}{l}\text { Wpływ na lojalność } \\
\text { pracowników i klien- } \\
\text { tów }\end{array}$ & $\begin{array}{l}\text { - Duża rotacja pracowników jest zagrożeniem dla } \\
\text { reputacji i efektywności brokera. } \\
\text { - Rosna ukryte koszty pracownicze i nakłady na re- } \\
\text { krutację (wzrost o } 42 \% \text { w ciągu ostatnich } 4 \text { lat). } \\
\text { - Rośnie czas rekrutacji odpowiednich pracowni- } \\
\text { ków (wzrost o 43\% w ciągu ostatnich } 4 \text { lat) [SARA- } \\
\text { TOGA 2015]. } \\
\text { - Rotacja także zwiększa m.in. ryzyko utraty danych } \\
\text { wrażliwych, podnosi ryzyko OC brokera. } \\
\text { - Problemy z pozyskiwaniem i utrzymywaniem ta- } \\
\text { lentów. } \\
\text { - Przy zwolnieniach grupowych w zakładach ubez- } \\
\text { pieczeń rośnie ryzyko braku odpowiedniej jakości } \\
\text { obsługi brokerów przez zakład ubezpieczeń. }\end{array}$ \\
\hline $\begin{array}{l}\text { Zmiany } \\
\text { konsumenckie }\end{array}$ & $\begin{array}{l}\text { Wpływ na utrzymanie } \\
\text { klienta }\end{array}$ & $\begin{array}{l}\text { - Zmiany podejścia klientów do lojalności. } \\
\text { - Problemy z zaufaniem do pośredników i ich repu- } \\
\text { tacją. }\end{array}$ \\
\hline \begin{tabular}{|l|} 
Inwestycje \\
zagraniczne
\end{tabular} & $\begin{array}{l}\text { Inwestycje bezpośred- } \\
\text { nie i pośrednie }\end{array}$ & $\begin{array}{l}\text { - Bardziej wymagający klienci, duża konkurencja } \\
\text { w segmencie dużych przedsiębiorstw. } \\
\text { - Nowi konkurenci na rynku ubezpieczeniowym } \\
\text { i brokerskim. } \\
\text { - Rosnące ryzyko polityczne, zmiany ratingu Polski } \\
\text { i zakładów ubezpieczeń. }\end{array}$ \\
\hline $\begin{array}{l}\text { Zmiany } \\
\text { technologiczne }\end{array}$ & $\begin{array}{l}\text { Wpływ na obsługę } \\
\text { brokera i klienta }\end{array}$ & $\begin{array}{l}\text { - Zmiana zasad underwritingu. } \\
\text { - Wykorzystanie BIG DATA. } \\
\text { - Wprowadzanie innowacji (towarzysz w życiu, do- } \\
\text { datkowa wartość, wygoda i prostota) } \\
\text { [BCG PIU 2016]. }\end{array}$ \\
\hline
\end{tabular}




\begin{tabular}{|c|c|c|}
\hline 1 & 2 & 3 \\
\hline $\begin{array}{l}\text { Efektywność } \\
\text { rynku ubezpie- } \\
\text { czeniowego }\end{array}$ & $\begin{array}{l}\text { Niewielka liczba do- } \\
\text { stępnych instrumen- } \\
\text { tów ubezpieczenio- } \\
\text { wych, coraz mniejsze } \\
\text { zainteresowanie inwe- } \\
\text { storów }\end{array}$ & $\begin{array}{l}\text { - W przypadku dużych strat bądź przeregulowania } \\
\text { istnieje ryzyko ucieczki kapitału z polskiego rynku. } \\
\text { - Trudności z ulokowaniem niektórych ryzyk. } \\
\text { - Efekt zarażania problemami finansowymi innych } \\
\text { uczestników rynku ubezpieczeniowego. }\end{array}$ \\
\hline Inflacja (deflacja) & $\begin{array}{l}\text { Wpływ na wyniki dzia- } \\
\text { łalności lokacyjnej oraz } \\
\text { na wysokość wypłaca- } \\
\text { nych odszkodowań }\end{array}$ & $\begin{array}{l}\text { - Malejąca inflacja (deflacja) może spowodować, że } \\
\text { zakłady ubezpieczeń stosujące „cash flow underwi- } \\
\text { ting” mogą mieć problemy z kompensacją strat na } \\
\text { działalności technicznej, przychodami z działalności } \\
\text { lokacyjnej - sytuacja obecna. } \\
\text { - Zbyt duża inflacja może doprowadzić do powsta- } \\
\text { wania tzw.,,starego portfela” i konieczności utworze- } \\
\text { nia dodatkowych rezerw, ale sprzyja subsydiowaniu } \\
\text { działalności ubezpieczeniowej wynikami działalno- } \\
\text { ści lokacyjnej (ze względu na wysoki poziom stóp } \\
\text { procentowych). } \\
\text { - Pojawianie się problemów z niedoubezpiecze- } \\
\text { niem/nadubezpieczeniem. }\end{array}$ \\
\hline $\begin{array}{l}\text { Polityka kursów } \\
\text { walutowych }\end{array}$ & $\begin{array}{l}\text { Wpływ zmian na lo- } \\
\text { katy i wysokość zobo- } \\
\text { wiązań (stabilność, wy- } \\
\text { mienialność) klientów } \\
\text { i brokerów }\end{array}$ & $\begin{array}{l}\text { - Niższy lub niepewny zwrot z inwestycji zagranicz- } \\
\text { nych lub denominowanych w walutach obcych. } \\
\text { - Zmiana wartości aktywów i zobowiązań. }\end{array}$ \\
\hline $\begin{array}{l}\text { Polityka } \\
\text { podatkowa } \\
\text { i dodatkowe } \\
\text { regulacje }\end{array}$ & $\begin{array}{l}\text { Wpływ na wyniki bran- } \\
\text { ży przez "żywioł regu- } \\
\text { lacyjny" }\end{array}$ & $\begin{array}{l}\text { - Wprowadzenie dodatkowych obciążeń koszto- } \\
\text { wych (podatek od aktywów, planowana „opłata Re- } \\
\text { ligi") i regulacyjnych (np. Solvency II, IDD, ustawa re- } \\
\text { klamacyjna, działalność UOKiK, rekomendacje KNF/ } \\
\text { ElOPA, nowe rozporządzenie UE z } 04.2016 \text { w spra- } \\
\text { wie ochrony danych osobowych) w jednym czasie } \\
\text { może spowodować nie tylko zmniejszenie atrakcyj- } \\
\text { ności inwestowania w branżę ubezpieczeniową, ale } \\
\text { także problemy z compliance. } \\
\text { - Rosnąca liczba aktów prawnych (w Polsce średnio } \\
1750 \text { rocznie w ostatnich } 3 \text { latach } \\
\text { [Grant Thornton 2016]. }\end{array}$ \\
\hline
\end{tabular}

Tabela 5. Najważniejsze elementy analizy zmian w ramach otoczenia makroekonomicznego brokera

Źródło: opracowanie własne na podstawie: Lisowski i Jaworski [2001].

\section{Podsumowanie}

Uwzględniając wpływ różnych czynników na branżę brokerską oraz strukturę i wyniki polskiego rynku ubezpieczeniowego, do głównych wyzwań stojących przed firmami brokerskimi w najbliższych latach w Polsce możemy zaliczyć m.in.:

- wprowadzanie innowacji produktowych w obsłudze,

- utrzymanie kluczowej kadry przy dużej rotacji w zakładach ubezpieczeń i zmianie podejścia nowego pokolenia do pracy (nowa kultura pracy), 
- zwiększenie lojalności klientów i zmniejszenie ich rotacji,

- utrzymanie możliwości finansowania nakładów inwestycyjnych przy coraz niższych przychodach prowizyjnych oraz słabnących możliwościach generowania dodatkowych dochodów z lokat,

- dywersyfikację działalności (działalność klasyczna vs. dodatkowe doradztwo, likwidacja szkód itp.),

- compliance - coraz większa liczba regulacji bezpośrednio i pośrednio wpływających na brokera ubezpieczeniowego,

- coraz większą kulturę roszczeniową polskich przedsiębiorstw i poszukiwanie finansowania szkód także w oparciu o OC brokera,

- problem zmiany systemów prowizyjnych - jako wynik implementacji Dyrektywy IDD oraz rozszerzania się zjawiska prokonsumeryzmu.

Dla większości międzynarodowych i dużych krajowych brokerów wyzwaniem staje się utrzymanie satysfakcjonującej dla akcjonariuszy stopy zwrotu z kapitału. Pośrednicy w celu polepszenia rentowności i konkurencyjności będą stawali przed problemem racjonalizacji i restrukturyzacji zatrudnienia oraz obniżenia kosztów administracyjnych. Kanał brokerski w Polsce czeka szereg istotnych zmian, które będą wpływać na jego rozwój. Pod względem prawnym najważniejszą zmianą będzie nowa dyrektywa unijna IDD i kolejne zmiany w prawie polskim, które zostaną wdrożone pod wpływem konsumeryzmu. Wśród czynników społeczno-ekonomicznych szczególne znaczenie ma świadomość ubezpieczeniowa i niskie zaufanie do sektora ubezpieczeniowego oraz do samego pośrednika ubezpieczeniowego. Nowe technologie natomiast będą wymagały od brokerów nakładów inwestycyjnych i wymuszą na nich korzystanie z nowych, dostępnych ułatwień kontaktu z klientami i zakładami ubezpieczeń. Istotny wpływ na działalność brokerów ubezpieczeniowych w Polsce będzie mieć również sytuacja w branży ubezpieczeniowej w Polsce i na świecie, gdyż wynagrodzenie brokera zależy przede wszystkim od składki płaconej przez klienta. Przewiduje się też zmiany pod względem profilu specjalizacji brokerskich (brokerzy - „monoliners”).

\section{Bibliografia}

BCG PIU (2016), Jak branża ubezpieczeniowa może odzyskać atrakcyjność?, Kongres Polskiej Izby Ubezpieczeń, The Boston Consulting Group.

Grant Thornton (2016), Biała Księga "Stop biurokratyzmowi!", Rekomendacje z III Polskiego Kongresu Gospodarczego, Pracodawcy RP, Polski Kongres Gospodarczy. 
KPMG (2015), Jeden klik od ubezpieczenia - czy Polacy sa gotowi na kanały cyfrowe?, Oczekiwania i zachowania konsumentów cyfrowych a skuteczne strategie ubezpieczycieli, Warszawa, grudzień.

Lisowski J. (2015), Wybrane aspekty konkurencji na rynku ubezpieczeniowym - ujęcie ekonomiczno-finansowe, [w:] M. Serwach (red.), Konkurencja i konkurencyjność na rynku ubezpieczeniowym, Fundacja Instytut Zarządzania Ryzykiem Społecznym, Warszawa.

Lisowski J. (2016), Część ekonomiczna, [w:] Raport 2016, Otoczenie prawno-ekonomiczne działalności brokerskiej, SPBUiR Polbrokers, Warszawa.

Lisowski J., Jaworski W. (2001), Niemierzalne elementy oceny zakładu ubezpieczeń, [w:] K. Jajuga, M. Łyszczak (red.), Finanse, bankowosć i ubezpieczenia, Prace Naukowe nr 899, t. 2, Wydawnictwo AE we Wrocławiu, Wrocław.

Porter M.E. (2006), Strategia konkurencji. Metody analizy sektorów i konkurentów, MT Biznes, Warszawa.

SARATOGA 2015, Human Capital Benchmarking. Podsumowanie wyników, Badania Saratoga w Edycji 2015, PWC.

UKNF 2009, Raport o stanie rynku brokerskiego w 2008 roku, Urząd Komisji Nadzoru Finansowego, Warszawa.

UKNF 2010, Raport o stanie rynku brokerskiego w 2009 roku, Urząd Komisji Nadzoru Finansowego, Warszawa.

UKNF 2011, Raport o stanie rynku brokerskiego w 2010 roku, Urząd Komisji Nadzoru Finansowego, Warszawa.

UKNF 2012, Raport o stanie rynku brokerskiego w 2011 roku, Urząd Komisji Nadzoru Finansowego, Warszawa.

UKNF 2013, Raport o stanie rynku brokerskiego w 2012 roku, Urząd Komisji Nadzoru Finansowego, Warszawa.

UKNF 2014, Raport o stanie rynku brokerskiego w 2013 roku, Urząd Komisji Nadzoru Finansowego, Warszawa.

UKNF 2015, Raport o stanie rynku brokerskiego w 2014 roku, Urząd Komisji Nadzoru Finansowego, Warszawa.

UKNF 2016, Raport o stanie rynku brokerskiego w 2015 roku, Urząd Komisji Nadzoru Finansowego, Warszawa.

\section{RYNEK BROKERSKI W POLSCE A ZMIANY OTOCZENIA EKONOMICZNEGO}

Brokerzy prowadzący działalność na polskim rynku ubezpieczeniowym muszą stawić czoła zmieniającym się warunkom rynkowym. Przede wszystkim rosnąca intensywność konkurencji oraz dynamiczne zmiany w otoczeniu powodują, że brokerzy muszą w większym stopniu zwracać uwagę na efektywność i dywersyfikację prowadzonej działalności. Uwzględniając wpływ różnych czynników na 
branżę brokerską oraz strukturę i wyniki polskiego rynku ubezpieczeniowego, do głównych wyzwań stojących przed firmami brokerskimi w najbliższych latach w Polsce możemy zaliczyć m.in.: wprowadzanie innowacji produktowych w obsłudze; utrzymanie kluczowej kadry; zwiększenie lojalności klientów i zmniejszenie ich rotacji; dywersyfikację działalności (działalność klasyczna vs. dodatkowe doradztwo, likwidacja szkód itp.); compliance - coraz większa liczba regulacji bezpośrednio i pośrednio wpływających na brokera ubezpieczeniowego.

Słowa kluczowe: broker ubezpieczeniowy, rynek brokerski, zmiany otoczenia ekonomicznego.

\section{BROKER'S MARKET IN POLAND AND THE CHANGING ECONOMIC ENVIRONMENT}

Brokers operating in the Polish insurance market must respond to changing market conditions. First of all, the growing intensity of competition and the dynamic changes in the environment cause that brokers have a greater focus on efficiency and diversification of its business. Taking into account the impact of various factors on the industry broker and the structure and performance of the Polish insurance market, the main challenges facing brokers in the next few years in Poland can include, among others: the introduction of product innovations to operate, maintain key personnel, increasing customer loyalty and reducing their rotation, diversification activity (classic vs. additional advice, claims handling, etc.) compliance - a growing number of regulations directly and indirectly affect the insurance broker.

Keywords: insurance broker, broker's market, changing economic environment. 